\title{
ANTIBODIES TO BRAIN AND THEIR RELATION TO DEMYELINIZATION
}

\author{
BY \\ L. C. KOLB * and B. BOLTON \\ From the Research Unit, the National Hospital, Queen Square, London. \\ (RECEIVED 1ST OCTOBER, 1939)
}

THE occurrence of encephalomyelitis or other neurologic disorders during the Pasteur treatment of rabies has stimulated interest in recent years in the relation of parenteral injections of brain to demyelinization in the nervous system. A short review of the subject is given by Hurst as a preliminary to his own report on an attempt to produce such lesions in rabbits. Hurst (1932) and later Schwentker and Rivers (1934) were unable to demonstrate any changes in the nervous system of rabbits receiving repeated injections of brain. Rivers (1933, 1935) and his co-workers have, however, shown large areas of demyelinization in the cerebrum of eight of sixteen monkeys which had received from 46 to 85 intramuscular injections of brain emulsion and brain extract. They likened the picture to that of Schilder's disease in man, although many eosinophils and unusual giant cells not characteristic of this disease were observed about the areas of myelin destruction.

It has been shown by Brandt, Guth, and Müller (1926) and Witebsky and Steinfeld (1928) that brain antibodies are formed in rabbits by the injection of heterologous brain tissue. Schwentker and Rivers report the presence of such antibodies on injection of homologous brain combined with pig serum, vaccine virus, or brain which has undergone autolysis. The suggestion has been made that degenerative diseases may be due to the formation of autogenous antibodies against the tissue affected. Masugi (1932), Smadel (1936), and others have produced glomerulonephritis in animals by reinjecting antikidney serum. The serum was obtained by repeated injections of kidney emulsion of one animal into another. It seemed worthwhile to determine whether a heterologous antibrain serum might not, when reinjected, bring about lesions in the nervous system.

\section{Methods}

Albino rats (Glaxo strain) and rabbits were used. With a sterile technique, the rats' brains were removed immediately after killing the animal. The brain was first cleared of blood by perfusing with sterile normal saline through the aorta until the return from the vena cava was clear. The brains were then minced with scissors and ground without an abrasive in a mortar until a smooth paste was formed. The emulsion was made by mixing the paste from $20 \mathrm{gm}$. of rat brain with 80 c.c. of normal saline and 20 c.c. of pig serum. As a

* This work was done while Dr. Kolb held a John and Mary R. Markle Foundation Fellowship. 
preservative phenol was added to make a 0.5 per cent. solution. The emulsion was subcultured and rejected if growth occurred in the culture medium.

Intraperitoneal injections of this material were given three times weekly for the first month and twice weekly thereafter. Five c.c. were injected the first week, 7.5 c.c. the second, and 10 c.c. thereafter. The rabbits were bled at the end of the fourth and twelfth weeks, when complement fixation tests for brain antibodies were performed.

Another series of rabbits received kidney emulsion prepared in the same way, though omitting the pig serum. This was given in similar doses.

The rats receiving blood serum intravenously from the rabbits injected with rat brain or kidney were divided into several groups. The first group were those who received serum from the rabbits after 1 month of brain injections. The second group were those who received serum from the rabbits after 3 months of injections. The latter group was divided into three subgroups : (1) those receiving serum from rabbits injected with brain emulsion and pig serum ; (2) those receiving serum from rabbits injected with kidney emulsion ; (3) those receiving normal rabbit serum. The amount of serum given intravenously at one time varied from $0 \cdot 15$ to $1 \cdot 0$ c.c. Five rats were included in each subgroup.

After death or after killing the rats the various organs and the brains were removed and fixed in 15 per cent. formol-saline. The internal organs were embedded in paraffin and stained with iron hæmatoxylin and Van Gieson. The rat brains were frozen, sectioned and stained with Sharlach R. and hæmatoxylin.

\section{Results}

Rabbits.-Six rabbits received injections of rat brain, one of cat brain, and one of kidney emulsion. Of the animals receiving rat brain emulsion plus pig serum, three started to lose weight after the third injection and two died suddenly after the sixth. In every instance it was possible to establish the cause of death. The first animal showed a long tear in the gut. The second and third died of peritonitis, the former within 24 hours of the last injections. The third became paralysed in the hind-quarters after the fourth injection, but was well again the next day. The animal then rapidly lost weight and was weak in the hind limbs immediately after the next injection and died following the sixth injection. A large abscess was found pointing in from the parietal peritoneum.

The other three rabbits gained weight and received respectively $29,25,24$ injections of brain emulsion. The rabbit given cat brain received 24 injections and the one receiving kidney 29 injections. These also remained in good health and gained weight.

Complement fixation tests using a dilution of the original saline emulsion of rat brain or kidney as antigens were made at the end of the first and third month of injections. Serum from all the rabbits were set up against both antigens. At the end of the first month no organ specific antibodies were present in any of the sera ; that from animals receiving brain as well as from the one receiving kidney completely fixed the complement in the presence of both kidney and brain antigens in dilution of one to forty. After three months, however, the reactions were organ specific. Serum from rabbits receiving 
brain emulsion plus pig serum in dilution as high as $1 / 80$ fixed complement in the presence of brain antigen. No complement fixation took place with kidney antigen except in one instance. In rabbit 7 complement was fixed in the presence of both antigens, but dilutions of serum were possible to $1 / 160$ in the presence of brain and only 1/40 in the presence of kidney.

The serum from the animal receiving cat brain fixed complement in the presence of both cat brain and rat brain antigen, the former to a dilution of 1/40 completely and with 30 per cent. hæmolysis at 1/80 and the latter completely to $1 / 160$. The antibodies are thus not species specific.

Rats. Group 1.-The first group of rats which was given serum showed no unusual behaviour during observation over a 2-months period. The maximal total amount of serum containing brain antibodies given to any rat was 3.0 c.c. The maximal total amount of serum containing kidney antibody given was 4.3 c.c. The animals were then killed with ether. No abnormal changes were seen in the tissues studied after death. It may be said that the rabbit serum at this time probably did not contain adequate amounts of brain or kidney antibody or toxin.

Group 2, subgroup 1.-Five rats were given serum from the rabbit inoculated repeatedly over 3 months with kidney emulsion. One rat died after three intravenous injections totaling 1.4 c.c. of serum, and another after receiving 4.4 c.c. of serum in seven injections. This rat showed marked ascites for a week before death. The urine contained much cellular debris, $0 \cdot 15 \mathrm{gm}$. per cent. of protein, and urea amounting to $388 \mathrm{mgm}$. per cent. The other three animals were killed with ether ; one showed great ascites, the others had no fluid in the abdominal cavity. These rats had received totals of $8 \cdot 2,5 \cdot 4$, and $5 \cdot 7$ c.c. of serum given in seven to eleven divided doses partially intravenously and partially intra-peritoneally. Before death blood urea determinations were respectively $119 \cdot 0,196 \cdot 0$, and $82.4 \mathrm{mgm}$. per cent. Urine and a blood pressure determination were not made as we were primarily interested in the problem of glomerulonephritis.

At autopsy the kidneys grossly were very swollen, soft, a pale greyish colour, in contrast to the ruddy, firm-textured organ of the normal rat. The capsule peeled easily from the organ. Microscopically both glomeruli and tubules showed marked cellular changes. Many tubules were greatly distended and filled with a colloid-like substance, while the walls of others showed extensive cellular proliferation, the lumen in places being obliterated. Many cells were swollen and contained colloid. Parenchymatous cell proliferation was also present. In the glomeruli there were a proliferation of cells and destruction of glomerular outline. In some areas the condition appeared to have progressed to one of cellular degeneration of the glomerular cells.

Subgroup 2.-The rabbits which had received brain emulsion and pig serum regularly for three months acted as donors of serum to this group. These six rats received respectively $6 \cdot 6,7 \cdot 0,7 \cdot 3,5 \cdot 5,5$ and 5 c.c. of serum in eight to ten injections spaced at 2 to 5-day intervals. At no time was their behaviour unusual in any way. Blood ureas on two at the end of the series of injections equalled $25 \cdot 2$ and $45 \cdot 2 \mathrm{mgm}$. per cent. 
After killing the animals with ether and examining the organs and brains as before, no pathological changes could be found.

Subgroup 3.-These rats received serum from a normal rabbit. These animals showed no ill effects and after death their organs were normal on both macroscopic and microscopic study.

\section{Discussion}

The inability to produce any lesions by the technique employed here throws doubt on suggestions that the demyelinizing diseases are due to the development of antibodies against brain tissue antibrain antibodies or to the autogenous development of a "cerebrotoxin." The fact we were able to produce glomerulonephritis as Masugi, Smadel, and others have done indicates that the technique employed was not at fault. The inability to produce lesions in either kidney or brain by intravenous injection of normal rabbit serum offers a negative control for these experiments.

It is interesting that we were able to give repeated massive intraperitoneal injections of brain emulsion to four rabbits over a period of three months without ill effect. Schwentker and Rivers noticed no weight loss in their large series of animals when giving injections intraperitoneally. On the other hand, Hurst concluded that brain emulsions had a definite toxic effect and caused weight loss with eventual death. He gave his injections intramuscularly. We are disinclined to believe that brain tissue per se has any toxic properties.

The results of the complement fixation tests is in agreement with those of Brandt, Guth and Müller, and Witebsky and Steinfeld, who described the presence of organ specific antibodies to brain on injection of heterologous brain. Witebsky pointed out that combination of brain emulsion with a foreign protein such as our pig serum often confused the result of the complement fixation reactions. This may serve to explain the ambiguous results which we obtained after only 4 weeks of inoculations.

\section{Summary}

It was found impossible to produce lesions in the brain of rats who had received injections of rabbit serum containing brain antibodies. The rabbits had received intraperitoneal injections of brain emulsion for 3 months, the technique corresponding to that employed by Masugi and others to produce experimental glomerulonephritis in animals. The result suggests that the demyelinization found in animals is probably not to be explained as due to the development of autogenous antibodies to brain or to some "cerebrotoxin" developed in the presence of brain lipoids.

\section{REFERENCES}

Brandt, R., Guth, H., and Müller, R. (1926). Klin. Wschr., 5, 655.

Hurst, E. W. (1932). J. Hyg., 32, 33.

Masugi, M., Sato, Y., Mirasawa, S., and Tomizuka, Y. (1932). Tr. Jap. path. Soc., $22,614$.

Rivers, T. M., Sprunt, D. H., and Berry, G. P. (1933). J. exp. Med., 58, 39.

Rivers, T. M. and Schwentker, F. F. (1935). Ibid., 61, 689.

Schwentker, F. F. and Rivers, T. M. (1934). Ibid., 60, 559.

Smadel, J. E. (1936). Ibid., 64, 921.

Witebsky, E. and Steinfeld, J. (1928). Z. ImmunForsch., 58, 271. 